ISSN (Print) : 1412-7601

ISSN (Online) : 2654-8712

Volume 6, No.2 September 2020

http://www.ekonobis.unram.ac.id

EKONOBIS

\title{
Analisis Pertumbuhan Ekonomi, Pengangguran Dan Kemiskinan Di Kabupaten Lombok Tengah
}

\author{
Muaidy Yasin, Muhammad Irwan, Wahyunadi. \\ Universitas Mataram
}

ARTICLE INFO

Keywords :

Economic Growth,

Unemployment and

Poverty

ABSTRACT : This study aims to determine economic growth, unemployment and poverty in Central Lombok Regency during 2012 - 2019. The type of research used is a descriptive method using secondary data which is analyzed using growth analysis. The results showed that the Gross Regional Domestic Product (GRDP) of Central Lombok Regency both based on current prices and constant prices in 2012-2019 continued to increase as well as the Gross Regional Domestic Product each capita. The sector that made the largest contribution in the formation of GRDP was the agricultural sector with an average of 25.10 percent, the transportation and warehousing sector an average of 20.40 percent, the construction sector an average of 11.56 percent. The economic growth of Central Lombok Regency in 2012-2019 is based on the average applicable price of 11.00 percent while based on the current price an average of 6.39 percent.

The number of unemployed people in Central Lombok Regency since 2012-2019 has decreased by an average of 1,776 people each year. The Rate of Open Unemployment in Central Lombok Regency in 2012 - 2019 averaged 4.84 The number of people classified as poor also experienced a decline from 148,200 people in 2012 to 128,820 people in 2019, a decrease on average as many as 2,423 people each year. The percentage of poor people is still relatively high at an average of 15.48 percent.

Kata Kunci :

Pertumbuhan Ekonomi, Pengangguran dan Kemiskinan
ABSTRAK: Penelitian ini bertujuan untuk mengetahui pertumbuhan ekonomi, pengangguran dan kemiskinan di Kabupaten Lombok Tengah selama tahun 2012 2019. Jenis Penelitian yang dipergunakan adalah metode deksriptif dengan menggunakan data sekunder yang dianalisis menggunakan analisis pertumbuhan. Hasil penelitian menunjukkan bahwa Produksi Domestik Regional Bruto (PDRB) Kabupaten Lombok Tengah baik berdasarkan harga berlaku maupun harga konstan tahun 2012-2019 terus mengalami peningkatan demikian halnya dengan Produk Domestik Regional Bruto Per kapita. Sektor yang memberikan kontribusi terbesar dalam pembentukan PDRB adalah sektor pertanian dengan rata-rata sebesar 25,10 persen, sektor transportasi dan pergudangan rata-rata sebesar 20,40 persen, sektor kontruksi rata-rata sebesar 11,56 persen. Pertumbuhan ekonomi Kabupaten Lombok Tengah pada tahun 2012-2019 berdasarkan harga berlaku rata-rata sebesar 11,00 persen sedangkan berdasarkan harga berlaku rata-rata sebesar 6,39 persen.

Jumlah penduduk yang menganggur di Kabupaten Lombok tengah sejak tahun 2012 2019 secara rata-rata mengalami penurunan sebesar 1.776 orang per tahun. Tingkat Pengangguran Terbuka (TPT) di Kabupaten Lombok Tengah tahun 2012 - 2019 ratarata sebesar 4,84 Jumlah penduduk yang tergolong miskin juga mengalami penurunan dari berjumlah 148.200 orang pada tahun 2012 menjadi sebanyak 128.820 orang pada tahun 2019, terjadi penurunan secara rata-rata sebanyak 2.423 orang pertahun. Secara persentase penduduk miskin masih relatif tinggi rata-rata sebesar 15,48 persen.

Corresponding Author :

Alamat : Program Studi Ekonomi Pembangunan, Fakultas Ekonomi dan Bisnis, Universitas Mataram, Jln. Majapahit No. 62 Mataram.

e-mail: M.Irwan@unram.ac.id 


\section{PENDAHULUAN}

Latar Belakang

Pembangunan ekonomi nasional sejak awal Orde Baru hingga saat ini telah memberikan hasil positif bagi masyarakat Indonesia, terutama jika dlihat dari sisi kinerja ekonomi makronya (Tambunan, 2019). Menurut Amartya Sen yang dikutip Pressman (2000), pembangunan (perkembangan) ekonomi adalah pengembangan kemampuan manusia yang berupa peningkatan harapan hidup, bebas buta huruf, serta peningkatan kesehatan dan pendidikan masyarakat. Pembangunan ekonomi adalah suatu proses yang menyebabkan kenaikan pendapatan riil perkapita peduduk suatu negara dalam jangka panjang yang disertai oleh perbaikan sistem kelembagaan (Arsyad, 2010). Pembangunan ekonomi adalah pembangunan kemakmuran ekonomi negara atau daerah guna kesejahteraan penduduknya (Huda, 2015). Pada umumnya pembangunan ekonomi dipusatkan pada usaha-usaha untuk meningkatkan pertumbuhan ekonomi (Subandi, 2019).

Pembangunan yang tengah dilaksanakan oleh suatu negara secara otomatis akan diikuti pula dengan proses pembangunan di daerah. Oleh karenanya pemerintah pusat telah memberikan peluang kepada daerah melalui Otonomi Daerah untuk membangun daerahnya. Kuncoro (2004) mengatakan bahwa berdasarkan survei beberapa literatur, terdapat beberapa sasaran fundamental pembangunan yang berusaha dicapai oleh banyak daerah adalah (1) Meningkatkan laju pertumbuhan ekonomi daerah; meningkatkan pendapatan per kapita; (3) mengurangi kemiskinan, pengangguran dan ketimpangan. Arsyad (2010) mengatakan bahwa setiap upaya pembangunan daerah mempunyai tujuan utama untuk meningkatkan jumlah dan jenis peluang kerja untuk masyarakat daerah. Fahmi (2018) mengatakan bahwa suatu pembangunan akan berlangsung dengan baik jika perangkat aturan yang mendukung ke arah tersebut termiliki oleh negara yang bersangkutan. Termasuk dalam hal ini perangkat dan aturan pelaksanaan otonomi daerah yang mendukung.

Pembangunan ekonomi pada dasarnya merupakan rujukan bagi pembangunan daerah atau dapat dikatakan dalam perencanaan pembangunan daerah, yaitu konsep pembangunan ekonomi yang disusun atau direncanakan oleh pemerintah pusat dijabarkan dalam rencana pembangunan daerah 
(Suwandika, dkk, 2015). Menurut Cheema dalam Sun'an, dkk (2015), terdapat empat faktor yang mempengaruhi keberhasilan pembangunan daerah yakni (1) aspek-aspek individu (indivudial aspects); seperti keahlian teknis, nilainilai, tingkah laku dan kepercayaan dari individu yang ada di dalam masyarakat (2) aspek-aspek lingkungan (environmental aspects); seperti struktur sosial dan politik; (3) ketersediaan sumber-sumber yang mendorong ide-ide inovatif dan program-program dan (4) aspek-aspek institusional (institutional aspects).

Kabupaten Lombok Tengah merupakan salah satu kabupaten yang berada di Provinsi Nusa Tenggara Barat, telah dan tengah melaksanakan proses pembangunan daerah untuk mencapai visi dan misi yang telah ditetapkan pada setiap priode pemerintahan daerah Kabupaten Lombok Tengah. Proses pembangunan di Kabupaten Lombok Tengah saat ini mengalami perkembangan yang cukup pesat terutama pembangunan fisik. Proses pembangunan tersebut di samping menggunakan dana pemerintah pusat juga memanfaatkan dana yang dimiliki dengan mengoptimalkan pemanfaatan sumberdaya daerah yang menghasilkan pendapatan daerah. Sisi lain, pemerirntah daerah Kabupaten
Lombok Tengah juga menghadirkan investor untuk melakukan Investasi baik investasi pemerirntah maupun swasta untuk melakukan aktivitas pembangunan ekonomi terutama berkenaan dengan investasi infrastruktur dan pariwisata. Sisi lainnya terdapat beberapa Perguruan Tinggi Negeri dibangun pula di daerah ini salah satunya IPDN yang diikuti oleh pembangunan sektor-sektor lainnya. Salah satu aktivitas pembangunan fisik yang tengah digalakkan dan menghantarkan daerah ini terkenal di dunia Internasional adalah ditetapkannya sebagai tempat pelaksanaan Balap Motor Internasional yang direncanakan akan dilaksanakan pada tahun 2021 mendatang. Daerah ini juga ditetapkan sebagai salah satu wilayah pengembangan ekonomi dengan pengembangan Kawasan Ekonomi Khusus yaitu Kawasan Ekonomi Khusus (KEK) Mandalika.

Proses pembangunan fisik tersebut juga dilaskanakan secara bersama dengan pembangunan ekonomi daerah kabupaten Lombok Tengah. Pembangunan ekonomi daerah adalah suatu proses di mana pemerintah dan masyarakatnya mengelola sumber dayasumber daya yang ada dan membentuk suatu pola kemitraan antara pemerintah daerah dengan sektor swasta untuk 
menciptakan suatu lapangan kerja baru dan merangsang perkembangan kegiatan ekonomi dalam wilayah tersebut (Sun'an, dkk, 2015). Dampak tersebut sudah dirasakan pada masa-masa yang baru liwat, masa sekarang maupun akan dirasakan pada masa mendatang. Kemampuan pemerintah daerah Kabupaten Lombok Tengah dalam melaksanakan proses pembangunan, terutama di dalam pembangunan ekonomi dapat dilihat dari kemampuannya merealisasikan hasil-hasil pembangunan berdasarkan anggaran yang telah direncanakan dan dialokasikan. Kinerja pembangunan ekonomi pemerintah Kabupaten Lombok Tengah dapat dilihat dari beberapa indikator utama yaitu Pertumbuhan Ekonomi, Pengangguran serta kemiskinan. Ketiga variabel ini adalah indikator utama untuk melihat kinerja pemerintah melaksanakan pembangunan ekonomi daerah. Diyakini bahwa tingkat pertumbuhan ekonomi, jumlah penduduk yang menganggur serta penduduk yang tergolong miskin mengalami perubahan dari tahun ke tahunnya. Perubahan tersebut akan menjadi pijakan pemerintah daerah Kabupaten Lombok Tengah untuk menetapkan langkah-langkah kebijakan yang akan mengarah pada terciptanya pembangunan ekonomi yang lebih baik dibanding tahun-tahun sebelumnya. Berdasarkan uraian pada latar belakang di atas, bagaimana tingkat pertumbuhan ekonomi, jumlah pengangguran dan kemiskinan di Kabupaten Lombok Tengah selama tahun 2012 -2019 .

\section{Tujuan dan Manfaat Penelitian}

Adapun tujuan penelitian ini adalah untuk mengetahui pertumbuhan ekonomi, pengangguran dan kemiskinan di Kabupaten Lombok Tengah selama tahun 2012 - 2019. Hasil tersebur dapat dijadikan landasan bagi berbagai pihak yang berkepentingan dengan proses pembangunan di Kabupaten Lombok Tengah khususnya pembangunan ekonomi.

\section{KAJIAN PUSTAKA}

\section{Pengertian Pertumbuhan Ekonomi}

Pertumbuhan ekonomi merupakan salah satu indikator makro untuk melihat kinerja perekonomian di suatu negara maupun daerah yang berada di dalam wilayah negara tersebut. Secara umum pertumbuhan ekonomi didefinisikan sebagai peningkatan dalam kemampuan dari suatu perekonomian dalam memproduksi barang-barang dan jasajasa. Dengan perkataan lain, pertumbuhan ekonomi lebih menunjuk 
pada perubahan yang bersifat kuantitatif (quantitative change) dan biasanya diukur dengan menggunakan data produk domestik bruto (GDP), atau pendapatan atau output perkapita (Nanga, 2001). Pertumbuhan ekonomi dapat menunjukkan sejauhmana aktivitas perekonomian akan menghasilkan tambahan pendapatan masyarakat pada suatu priode tertentu (Pangiuk, 2018) .

Jhingan (2018) mengatakan pertumbuhan atau perkembangan ekonomi didefinisikan dalam 3 cara yaitu (1) perkembangan ekonomi harus diukur dalam arti kenaikan pendapatan nasional nyata dalam suatu jangka waktu yang panjang. (2) Mengutip pendapat dari Prof. Meier, perkembangan ekonomi sebagai suatu proses kenaikan pendapatan nyata per kapita dalam suatu jangka waktu yang panjang. (3) perkembangan ekonomi dengan mengutip pendapat Okun dan Richardson, perkembangan ekonomi adalah perbaikan terhadap kesejahteraan material yang terus menerus dan berjangka panjang yang dapat dilihat dari lancarnya distribusi barang dan jasa. Menurut Arsyad (2010), terdapat 4 faktor utama yang memeengaruhi pertumbuhan ekonomi suatu masyarakat (negara) yaitu (1) Akumulasi modal termasuk semua investasi baru yang berwujud tanah (lahan, peralatan fisik, mesin-mesin) dan sumber daya manusia; (2) Pertumbuhan penduduk yang berkaitan dengan kenaikan jumlah angkatan kerja (labor force); (3) Kemajuan teknologi yang disebabkan oleh adanya cara-cara baru atau mungkin cara-cara lama yang diperbaiki dalam melakukan pekerjaanpekerjaan tradisional; (4) sumber daya institusi (kelembagaan) yang artinya mengutip pendapat North (1991) adalah aturan-aturan yang mengatur interaksi politik, ekonomi dan sosial.

Kuncoro (2013), membedakan antara pertumbuhan ekonomi dan pembangunan ekonomi. Menurutnya, memang pertumbuhan ekonomi hanya mencatat peningkatan produksi barang dan jasa secara nasional, sedang pembangunan ekonomi berdimensi lebih luas dari sekedar peningkatan pertumbuhan ekonomi. Dalam konteks negara, pertumbuhan ekonomi suatu negara (rate of economic growth, rog) dihitung dengan:

Rog $=($ PDBt-PDBt-1)/PDBt-1x100\% PDBt $=$ Produk Domestik Bruto suatu negara pada tahun $\mathrm{t}$;

PDBt-1 = Produk Domestik Bruto suatu negara pada tahun $\mathrm{t}-1$.

Pertumbuhan ekonomi wilayah adalah pertumbuhan pendapatan masyarakat 
secara keseluruhan yang terjadi pada wilayah tersebut, yaitu kenaikan seluruh kenaikan nilai tambah yang terjadi (Pangiuk, 2018). Pertumbuhan ekonomi wilayah (provinsi/kabupaten/kota) dapat dihitung dari besarnya nilai PDRB dari masing-masing daerah setiap tahun. Formulasinya dengn merubah formulasi di atas menjadi :

Rog $=($ PDRBt-PDRBt-1)/PDRBt-1x100\%

PDRBt $=$ Produk Domestik Regional Bruto suatu daerah pada tahun $\mathrm{t}$;

PDRBt-1 = Produk Domestik Regional Bruto suatu daerah pada tahun t-1 baik Atas Dasar Harga Berlaku (ADHB) maupun Atas Dasar Harga Konstan (ADHK).

\section{Pengertian Pengangguran}

Pengangguran dalam pengertian makro ekonomi adalah sebagian dari angkatan kerja yang sedang tidak mempunyai pekerjaan,. Dalam pengertian mikro pengangguran adalah keadaan seorang yang mampu dan mau melakukan pekerjaan akan tetapi sedang tidak mempunyai pekerjaan (Suroto, 1992). Pengangguran pada prinsipnya mengandung arti hilangnyapoutput (loss of output) dan kesengsaraan bagi orang yang tidak bekerja (human misery) dan merupakan suatu bentuk pemborosan sumber daya ekonomi (Nanga, 2001). Orang yang tidak mau bekerja tidak dapat dikatakan sebagai pengangguran, sebab jika ia mencari pekerjaan (ingin bekerja) mungkin dengan segera mendapatkannya. Sebab definisi ekonomi tentang pengangguran tidak identik dengan tidak (mau) bekerja. Seseorang baru dikatakan menganggur bila dia ingin bekerja dan telah berusaha mencari kerja, namun tidak mendapatkannya (Rahardja, 2004). Pengangguran (unemployment) adalah suatu keadaan di mana seseorang yang tergolong dalam katagori angkatan kerja tidak memiliki pekerjaan dan secara aktif sedang mencari pekerjaan (Sumarsono, 2009).

Soeroto (1992) membedakan definisi penganggur dan pengangguran. Penganggur adalah orang yang mampu bekerja, tidak mempunyai pekerjaan, dan ingin bekerja atau baik secara aktif, maupun pasti mencari pekerjaan. Dia adalah anggota angkatan kerja yang tidak mempunyai pekerjaan. Sedangkan pengangguran adalah kejadiaan atau keadaan orang yang sedang menganggur. Pengangguran tidak sama dengan tidak bekerja atau tidak mau bekerja. Penganggur adalah mereka yang segang mencari pekerjaan, atau mereka yang mempersiapkan usaha, atau mereka yang tidak mencari pekerjaan karena merasa tidak mungkin mendapatkan pekerjaan 
(sebelumnya dikatagorikan sebagai bukan angkatan kerja), dan mereka yang sudah punya pekerjaan tetapi belum mulai bekerja (sebelumnya dikatagorikan sebagai pekerja), dan pada waktu yang bersamaanmereka tidak bekerja (jobless). Penganggur dengan konsep/definisi tersebut biasanya disebut sebagai penganggur terbuka atau Open unemployment (Kuncoro, 2013).

Badan Pusat Statistiik mendefinisikan penganggur adalah penduduk yang tidak bekerja tetapi berharap mendapat pekerjaan, dan kegiatannya terdiri dari encari pekerjaan, mempersiapkan usaha, tidak mencari pekerjaan karena alasan merasa tidak mungkin mendapatkan pekerjaan (putus asa), tidak mencari pekerjaan karena sudah mempunyai pekerjaan tetapi belum mula bekerja. Mankiw, dkk (2008) mengatakan bahwa seseroang dikatgorikan bekerja jika ia menghabiskan beberapa hari pada minggu sebelumnya untuk mengerjakan pekerjaan yang dibayar. Kemudian seseoran dianggap pengangguran jika ia berhenti bekerja semetara atau sedang mencari pekerjaan.

Mulyadi (2012) mengatakan Tingkat pengangguran (Unemployment) adalah angka yang menunjukkan berapa banyak dan jumlah angkatan kerja yang sedang aktif mencari pekerjaan. Pengertian menganggur disini adalah aktif mencari pekerjaan. Sedang Pengangguran terbuka (Open Unemployment) atau pengangguran adalah bagian dari angkatan kerja yang sekarang ini tidak bekerja dan sedang aktif mencari pekerjaan.

$T^{P}=\frac{\text { Iumlak orang yang mencart pekerjaan }}{\text { JumLah angkatan kerja }} \times 100 \%$ Tingkat Pengangguran terbuka menurut BPS adalah rasio jumlah penganggur terbuka terhadap jumlah angkatan kerja atau dengan formulasinya adalah :

$T P T=\frac{\text { Jumlah Pengangguran Terbuka }}{\text { Jumlah Angkatan Kerja }} \times 100 \%$ Berdasarkan beberapa pengertian dari pengangguran maupun Tingkat pengangguran terbuka, yang diacu dalam tulisan ini adalah konsep/definisi dan formulasi yang berasal dari Badan Pusat Statistik.

\section{Pengertian Kemiskinan}

Secara tradisional kemiskinan adalah pendapatan yang rendah atau tidak berpendapatan. Pemaknaan tradisional ini tercermin dari definisi yang digunakan oleh Bank Dunia yang menjadikan ukuran US\$ 2 per hari sebagai standar minimum garis kemiskinan (Stamboel, 2012). Menurut Yohandarwati, dkk yang dikutip oleh Maipita (2014), kebutuhan ekonomi , emosional, sosial dan politik sangat 
berafam bagi setiap orang. Oleh karena itu, pengertian "miskin" itu biasanya dipersempit hanya miskin secara ekonomi. Pengertian miskin secara ekonomi juga dipersempit lagi sebagai ketidakmampuan dalam memenuhi kebutuhan pokok atau kebutuhan dasar berupa kebutuhan pangan dan non pangan.

Pengertian kemiskinan dalam tulisan ini merujuk pada konsep yang dipergunakan oleh Badan Pusat Statistik yang memiliki keweangan untuk menghitung jumlah dan persentase penduduk yang tergolong miskin. Untuk mengukur kemiskinan, BPS menggunakan konsep kemampuan untuk memenuhi kebutuhan dasar (basic needs aaproach). Dengan pendekatan ini kemiskinan dipandang sebagai ketidakmampuan dari sisi ekonomi untuk memenuhi kebutuhan dasar makanan dan non makanan yang diukur dari sisi pengeluaran. Dengan pendekatan ini dapat dihitung Headcount Index, yaitu persentase penduduk miskin terhadap total penduduk.

Metode yang digunakan adalah menghitung garis kemiskinan (GK) yang diartikan sebagai tingkat pendapatan atau pengeluaran yang ditetapkan, dimana bila pendapatan seseorang berada di bawah garis kemiskinan, maka ia dikatakan miskin. Oleh karena itu, garis kemiskinan sangat berpengaruh terhadap besar kecilnya angka kemiskinan (Maipita, 2014). Garis kemiskinan terdiri dari dua komponen yaitu (1) Garis Kemiskinan Makanan (GKM) yaitu pengeluaran kebutuhan minimum makanan yang disetarakan dengan 2.100 kalori per kapita per hari; (2) Garis kemiskinan Bukan Makanan (GKBM) yaitu kebutuhan minimum untuk perumahan, sandang, pendidikan dan kesehatan, yang diwaikili oleh 51 jenis komoditas di perkotaan dan 47 jenis komoditas di daerahpedesaan.

\section{METODE PENELITIAN}

\section{Jenis Penelitian yang Dipergunakan}

Jenis Penelitian yang dipergunakan adakan metode deksriptif yang menggambarkan kinerja perekonomian kabupaten Lombok Tengah pada priode waktu 2012- 2019 yang terfokus pada kajian tentang Pertumbuhan Ekonomi, Pengangguran dan Kemiskinan.

\section{Lokasi Penelitian dan Metode Penelitian}

Penelitian ini mengambil lokasi di Kabupaten Lombok Tengah Provinsi Nusa Tenggara Barat. Alasan yang mendasarinya karena Kabupaten Lombok Tengah merupakan salah satu Kabupaten yang berada di Provinsi Nusa Tenggara Barat mengalami perkembangan yang 
cukup cepat terutama dilihat dari aspek pembangunan ekonomi. Banyak potensi yang dapat dikembangkan di daerah ini sehingga berdampak pada peningkatan nilai tambah sektor-sektor ekonomu yang pada akhirnya akan berdampak pada terciptanya kesempatan kerja baru, mengurangi penduduk yang tergolong penganggur dan berdampak pula pada perubahan jumlah penduduk yang masih berada dalam kemiskinan.

\section{Data Yang Dipergunakan}

Penelitian ini menggunakan data sekunder yang diperoleh dari berbagai instansi yang berkaitan langsung dengan penelitian ini. Jenis data yang dibutuhkan adalah data yang berkaitan dengan PDRB kabupaten Lombok Tengah, Pendapatan Perkapita, Jumlah Penduduk yang Menganggur, Tinkat Pertumbuhan Terbuka (TPT) dan jumlah serta persentase penduduk miskin semuanya dari tahun 2012- 2019.

\section{Analisis Data}

Data kuantittatif yang diperoleh dianalisis dengan mempergunakan analisis pertumbuhan pada masing-masing variabel penelitian. Formulasi yang dipergunakan untuk menghitung pertumbuhan ekonomi, pengangguran Terbuka (TPT) maupun kemiskinan menggunakan formulasi yang telah diuraikan pada tinjauan pustaka. Perbedaannya, pertumbuhan ekonomi Kabupaten Lombok Tengah mengacu pada data PDRB (Produk Domestik Regional Bruto) baik berdasarkan pada harga Berlaku maupun harga Konstan tahun 2010 selama kurun waktu 2012-2019. Hasil dari perhitungan tersebut dilakukan secara kualitatif dengan mengacu pada tabel-tabel dan grafik.

\section{HASIL DAN PEMBAHASAN}

Kinerja pembangunan daerah dikatakan dapat berjalan dengan baik bila pemerintah daerah mampu meningkatkan perekonomiannya yang dilihat dari beberapa indikator pembangunan ekonomi. Kinerja perekonomian Kabupaten Lombok Tengah dapat dilihat dari beberapa indikator seperti Pertumbuhan Ekonomi, Pengangguran dan Kemiskinan. Sebelum menganalisis pertumbuhan ekonomi, dilakukan analisis Perkembangan Domestik Regional Bruto (PDRB) Kabupaten Lombok Tengah sebagai dasar untum menganalisis Pertumbuhan Ekonomi.

\section{Produk Domestik Regional Bruto} (PDRB) dan Pertumbuhan Ekonomi.

1. Produk Domestik Regional Bruto (PDRB) 
Produk Domestik Regional Bruto (PDRB) merupakan besarnya nilai tambah yang diperoleh pemerintah daerah dari aktivitas beberapa sektor ekonomi, yang mencerminkan kemampuan pemerintah daerah untuk menghasilkan produkproduk yang berasal dari dalam daerah dari berbagai sektor ekonomi selama satu tahun tertentu. Besar kecilnya nilai PDRB yang diperoleh kabupaten Lombok Tengah, merupakan salah satu indikator makro untuk melihat keberhasilan pembangunan ekonominya, sekaligus sebagai bahan untuk melakukan evaluasi terhadap proses pembangunan yang telah berjalan dan sebagai dasar untuk Tabel 1. Produk Domestik Regional Bruto (PDRB) Kabupaten Lombok Tengah Tahun 20122019.

\begin{tabular}{lll}
\hline Tahun & \multicolumn{2}{l}{ Total Nilai PDRB (Rp juta) } \\
\cline { 2 - 3 } & Atas Dasar Harga Berlaku & Atas Dasar Harga Konstan 2010 \\
$\mathbf{2 0 1 2}$ & $9.154 .772,60$ & $8.616 .438,70$ \\
$\mathbf{2 0 1 3}$ & $10.243 .517,10$ & $9.153 .911,30$ \\
$\mathbf{2 0 1 4}$ & $11.665 .561,80$ & $9.728 .881,10$ \\
$\mathbf{2 0 1 5}$ & $13.125 .820,00$ & $10.271 .861,90$ \\
$\mathbf{2 0 1 6}$ & $14.423 .750,00$ & $10.853 .939,10$ \\
$\mathbf{2 0 1 7}$ & $15.789 .210,00$ & $11.551 .690,00$ \\
\hline $\mathbf{2 0 1 8}$ & $16.750 .500,00$ & $11.918 .410,00$ \\
\hline $\mathbf{2 0 1 9}$ & $17.881 .010,00$ & $12.403 .660,00$ \\
\hline
\end{tabular}

Sumber : BPS, NTB dan BPS Kabupaten Lombok Tengah 2013 - 2020.

Selama kurun waktu 2012-2019, mengalami peningkatan dari tahun ke perkembangan nilai PDRB kabupaten tahunnya. Rata-rata peningkatan PDRB Lombok Tengah secara perlahan terus berdasarkan harga berlalu sebesar $\mathrm{Rp}$ 
1.246.605,34,- peningkatan tertinggi terjadi pada tahun 2015 sebesar Rp 1.460.258,30,- dan terendah terjadi pada tahun 2018 sebesar Rp 961.290,00,-Sedangkan rata-rata peningkatan PDRB berdasarkan harga konstan sebesar $\mathrm{Rp}$ 541.031,61,-.dengan peningkatan tertinggi terjadi pada tahun 2017 sebesar Rp 697.750,90,- dan peningkatan yang terendah terjadi pada tahun 2019 sebesar Rp 366.720,00,--

Peningkatan ini memberikan indikasi bahwa sektor-sektor perekonomian yang berada di Kabupaten Lombok Tengah telah menghasilkan produk-produk yang mampu memberikan nilai tambah bagi penerimaan domestik pemerintah Kabupaten Lombok Tengah. Peningkatan produk-produk yang dihasilkan oleh setiap sektor ekonomi juga telah berkontribusi dalam memenuhi berbagai kebutuhan masyarakat terhadap produk-produk yang dihasilkan tersebut.

Adanya nilai PDRB yang terus meningkat dari tahun ke tahun juga menunjukkan adanya peningkatan nilai PRDB yang diperoleh setiap penduduk Kabupaten Lombok Tengah yang dicerminkan dari besarnya PDRB per kapita seperti terlihat dalam tabel berikut.

\section{Tabel 2. Produk Domestik Regional Bruto (PDRB) Perkapita Kabupaten Lombok Tengah}

Tahun 2012- 2019.

\begin{tabular}{lll}
\hline Tahun & \multicolumn{2}{l}{ Nilai PDRB Per kapita (Rp) } \\
\cline { 2 - 3 } & Atas Dasar Harga Berlaku & Atas Dasar Harga Konstan \\
$\mathbf{2 0 1 2}$ & $10.536 .109,20$ & $9.916 .547,68$ \\
\hline $\mathbf{2 0 1 3}$ & $11.618 .101,12$ & $10.382 .280,43$ \\
$\mathbf{2 0 1 4}$ & $12.912 .209,84$ & $10.768 .564,46$ \\
$\mathbf{2 0 1 5}$ & $14.378 .488,28$ & $11.252 .161,46$ \\
$\mathbf{2 0 1 6}$ & $15.642 .487,48$ & $11.771 .044,74$ \\
$\mathbf{2 0 1 7}$ & $16.963 .107,96$ & $12.410 .536,35$ \\
$\mathbf{2 0 1 8}$ & $17.830 .891,55$ & $12.687 .136,27$ \\
$\mathbf{2 0 1 9}$ & $18.715 .672,86$ & $12.982 .647,11$ \\
\hline
\end{tabular}

Sumber : Kabupaten Lombok Tengah Dalam Angka 2013 -2020; diolah.

Berdasarkan tabel di atas pendapatan per kapita penduduk kabupaten Lombok

Tengah baik berdasarkan harga berlaku maupun harga konstan cenderung mengalami peningkatan dari tahun ke tahun. Peningkatan pendapatan perkapita akan menyebabkan terjadinya peningkatan daya beli terhadap berbagai 
barang maupun jasa yang dibutuhkan oleh masyarakat. Adanya daya beli yang meningkat akan merangsang produsen untuk memproduksi barang dan jasa, diimbangi dengan kondisi harga (inflasi) yang terkendali, menyebabkan meningkatnya keuntungan yang diperoleh produsen. Siklus ini akan terus berlangsung yang pada akhirnya terjadi peningkatan nilai tambah yang tercermin dari nilai PDRB.

Pendapatan per kapita penduduk Kabupaten Lombok Tengah secara ratarata meningkat sebesar $\mathrm{Rp} 1.168 .509,10,-$ berdasarkan harga berlaku, dengan peningkatan tertinggi terjadi pada tahun 2017 sebesar $\operatorname{Rp} 1.320 .620,48,-$. Sedangkan rata-rata peningkatan pendapatan perkapita berdasarkan harga berlaku sebesar $\operatorname{Rp} 428.644,20,-$ dengan pendapatan tertinggi juga terjadi pada tahun 2017 sebesar Rp 639.491,60,-Terjadinya peningkatan pendapatan perkapitan ini menyebabkan masyarakat akan melakukan konsumsi terhadap berbagai jenis barang maupun jasa yang menjadi kebutuhannya. Meskipun ratarata peningkatan PDRB per kapita masih lebih kecil dari rata-rata peningkatan PDRB, namun penduduk Kabupaten Lombok Tengah telah mampu meningkatkan kualitas hidupnya.

Perkembangan nilai PRDB maupun PDRB per kapita di kabupaten Lombok Tengah selama tahun 2012-2019 juga dapat dilihat dari peran sektor-sektor yang memberikan kontribusi terhadap pembentukan total nilai PDRB pada tahun tersebut. Sektor pembentuk PDRB yang memberikan kontribsui cukup besar terjadi pada beberapa sektor seperti terlihat berikut.

Tabel 3. PDRB Kabupaten Lombok Tengah Berdasarkan Distribusi Sektor Tahun 2012 2019.

\begin{tabular}{|c|c|c|c|c|c|c|c|c|c|}
\hline \multirow[t]{2}{*}{ No } & \multirow[t]{2}{*}{ Sektor PDRB } & \multicolumn{8}{|c|}{ Kontribusi Per Tahun ( \%) } \\
\hline & & 2012 & 2013 & 2014 & 2015 & 2016 & 2017 & 2018 & 2019 \\
\hline \multirow[t]{3}{*}{1} & Pertanian, & 26,5 & 24,9 & 24,5 & 24,8 & 24,7 & 24,95 & 25,3 & 24,8 \\
\hline & Kehutanan & 1 & 8 & 6 & 9 & 5 & & 6 & \\
\hline & Perikanan & & & & & & & & \\
\hline \multirow[t]{2}{*}{2} & Pertambangan dan & 3,78 & 3,73 & 3,70 & 3,70 & 3,79 & 3,91 & 4,04 & 4,98 \\
\hline & Penggalian & & & & & & & & \\
\hline
\end{tabular}




\begin{tabular}{|c|c|c|c|c|c|c|c|c|c|}
\hline 3 & $\begin{array}{l}\text { Industri } \\
\text { Pengolahan }\end{array}$ & 5,99 & 5,57 & 5,33 & 4,93 & 4,85 & 4,79 & 4,67 & 4,63 \\
\hline 4 & $\begin{array}{l}\text { Perdagangan Besar, } \\
\text { Reparasi Mobil dan } \\
\text { Sepeda Motor }\end{array}$ & $\begin{array}{l}10,5 \\
8\end{array}$ & $\begin{array}{l}10,3 \\
8\end{array}$ & $\begin{array}{l}10,5 \\
2\end{array}$ & $\begin{array}{l}10,4 \\
8\end{array}$ & $\begin{array}{l}10,8 \\
3\end{array}$ & 11,09 & $\begin{array}{l}11,4 \\
8\end{array}$ & $\begin{array}{l}11,8 \\
4\end{array}$ \\
\hline 5 & Konstruksi & $\begin{array}{l}11,3 \\
6\end{array}$ & $\begin{array}{l}10,8 \\
4\end{array}$ & $\begin{array}{l}10,8 \\
6\end{array}$ & $\begin{array}{l}11,1 \\
3\end{array}$ & $\begin{array}{l}11,3 \\
5\end{array}$ & 11,47 & $\begin{array}{l}11,9 \\
9\end{array}$ & $\begin{array}{l}13,6 \\
2\end{array}$ \\
\hline 6 & $\begin{array}{l}\text { Transportasi dan } \\
\text { Pergudangan }\end{array}$ & 18,1 & $\begin{array}{l}21,4 \\
3\end{array}$ & $\begin{array}{l}22,0 \\
4\end{array}$ & $\begin{array}{l}22,9 \\
1\end{array}$ & $\begin{array}{l}21,4 \\
6\end{array}$ & 20,89 & $\begin{array}{l}19,0 \\
4\end{array}$ & $\begin{array}{l}17,3 \\
3\end{array}$ \\
\hline 7 & Real Estate & 3,5 & 3,54 & 3,66 & 3,61 & 3,67 & 3,66 & 3,77 & 3,76 \\
\hline 8 & $\begin{array}{l}\text { Administrasi } \\
\text { Pemerintahan, } \\
\text { Pertahanan dan } \\
\text { Jaminan Sosial } \\
\text { Wajib }\end{array}$ & 6,26 & 5,94 & 6,66 & 6,07 & 5,84 & 5,6 & 5,57 & 5,43 \\
\hline 9 & Jasa Pendidikan & 4,8 & 4,57 & 4,29 & 4,33 & 4,42 & 4,41 & 4,51 & 4,13 \\
\hline
\end{tabular}

Sumber : BPS Loteng, Diolah.

Berdasarkan tabel di atas terlihat bahwa dari 17 sektor-sektor pembentuk PDRB di Kabupaten Lombok Tengah terdapat sembilan sektor yang memiliki kontribusi lebih tinggi dibandingkan dengan sektorsektor lainnya. Sektor Pertanian, Kehutanan dan Perikanan masih memberikan kontribusi terbesar terhadap distribusi PDRB, meski terus mengalami penurunan. Hal ini sejalan dengan kondisi yang terjadi secara nasional, bahwa peranan sektor pertanian cenderung mengalami penurunan dari tahun ke tahun terhadap pembentukan nilai Produk Domestik Bruto (PDB) maupun PDRB. Hal ini mengindikasikan bahwa telah terjadi transformasi ekonomi, dimana sektorsektor non pertanian mengalami peranan yang meningkat dibanding sektor pertanian, kehutanan dan perikanan yang cenderung mengalami penurunan. Artinya, sektor pertanian secara perlahan peranannya akan semakin berkurang dan akan menyebabkan terjadinya perubahan struktur perekononian dari sektor pertanian berubah menjadi sektor non pertanian. Secara rata-rata kontribusi sektor pertanian terhadap pembentukan PDRB Kabupaten Lombok Tengah tahun 2012-2019 sebesar 25,10 persen. 
Sektor non pertanian yang memberikan kontribusi yang paling tinggi terhadap pembentukan PDRB Kabupaten Lombok Tengah adalah sektor Transportasi dan Pergudangan rata-rata mencapai sebesar 20,40 persen. Kontribusi sektor ini meskipun beberapa tahun terakhir mengalami penurunan, namun masih menempati urutan kedua setelah sektor pertanian dalam arti luas. Hal ini memberikan makna bahwa seiring semakin membaiknya infrasruktur akan semakin mendorong terjadinya peningkatan sarana transportasi lainnya, sehingga memberikan dampak terhadap meningkatnya PDRB Kabupaten Lombok Tengah. Besarnya penerimaan PDRB sektor ini juga ditopang oleh semakin berkembangnya aktivitas masyarakat di sektor pariwisata yang juga memanfaatkan moda transportasi yang berdampak pada meningkatnya permintaan terhadap sarana-sarana transportasi khususnya kendaraan roda empat baik yang berukuran besar maupun ukuran sedang.

Aktivitas pembangunan fisik yang terus dilakukan di Kabupaten Lombok Tengah menyebabkan permintaan terhadap barang dan jasa yang berkenaan dengan pembangunan tersebut semakin meningkat pula. Hal ini ditunjukkan oleh semakin besarnya kontribusi yang diberikan oleh sektor kontruksi terhadap pembentukan PDRB kabupaten Lombok Tengah. Secara rata-rata kontribusi sektor kontruksi terhadap total PDRB Kabupaten Lombok Tengah sebesar 11,58 persen. Kontribusi tertinggi terjadi pada tahun 2019 sebesar 13,62 persen terjadi lompatan yang cukup besar dibanding tahun-tahun sebelumnya. Hal ini sejalan dengan semakin maraknya proses pembangunan fisik yang tengah berlangsung di kabupaten Lombok Tengah hingga saat sekarang. Besarnya kontribusi sektor transportasi, pergudangan dan sektor kontruksi berdampak pada meningkatnya kontribusi sektor perdagangan besar, reparasi mobil dan sepeda motor yang secara rata-rata mencapai sebesar 10,90 persen.

Sektor industri pengolahan yang diharapkan akan mampu menggantikan peran sektor pertanian dengan hadirnya usaha-usaha formal maupun informal di daerah pedesaan belum mampu memberikan kontribusi yang tinggi. Secara rata-rata kontribusi sektor industri pengolahan baru mencapai 5,10 persen masih lebih kecil dari kontribusi sektor Adiministrasi pemerintahan, pertahanan dan jaminan sosial wajib yang secara ratarata berkontribusi sebesar 5,92 persen. 
Hal ini mengindikasikan bahwa potensi industri pengolahan (formal dan formal) masih belum dikelola secara maksimal sehingga belum mampu memberikan hasil yang lebih banyak, bahkan sejak tahun 2013-2019 kontribusinya terhadap total pembentukan PDRB Kabupaten Lombok Tengah terus mengalami penurunan.

Kinerja sektor-sektor ekonomi pembentuk PDRB Kabupaten Lombok Tengah telah menunjukkan terjadinya pergeseran peran dari sektor pertanian menuju sektor non pertanian. Menghadapi kondisi yang demikian. bagi pemerintah daerah Kabupaten Lombok Tengah tengah dan harus mempersiapkan pembangunan infrastruktur yang berkenaan dengan pengembangan sektor jasa, baik dalam perdagangan maupun transportasi. Ditetapkannya Kabupaten Lombok Tengah sebagai salah satu kawasan ekonomi khusus (KEK) Mandalika, serta semakin banyaknya potensi-potensi wisata yang baru dibuka, maka akan diikuti oleh perkembangan sektor-sektor ekonomi lainnya. Perkembangan sektor pariwisata misalnya, akan diikuti oleh perkembangan sektor perdagangan, serta sektor-sektor jasa lainnya. Keterkaitan pembangunan antar sektor akan menjadi hal yang pasti terjadi, sehingga diperlukan adanya interaksi dan jaringan kerja yang baik para pelaku pada masing-masing sektor ekonomi.

Meskipun sektor pertanian peranannya semakin mengalami penurunan, namun sektor lainnya tidak akan berkembang tanpa adanya sektor pertanian. Aktivitas sebahagian besar penduduk Kabupaten Lombok Tengah hingga saat ini masih terkosentrasi pada sektor pertaniah, sehingga pengembangan sektor ini merupakan suatu keniscayaan. Adanya sinergisitas dan jaringan kerja yang baik akan menyebabkan aliran barang dan jasa berjalan dengan baik, sehingga setiap pelaku ekonomi benar-benar akan mendapatakan manfaat dari aktivitas usaha yang dilakukannya. Hal ini akan berdampak pada besar kecilnya nilai PDRB yang diperoleh sekaligus mencerminkan terjadinya pertumbuhan ekonomi kabupaten Lombok Tengah.

\section{Pertumbuhan Ekonomi}

Pertumbuhan ekonomi sebagaimana yang telah diuraikan di atas, merupakan salah satu variabel ekonomi makro yang dijadikan indikator untuk menilai keberhasilan pembangunan suatu negara maupun daerah. Hakikat pertumbuhan dan pembangunan ekonomi adalah suatu proses yang ditunjukkan dengan kebijakan pemerintah dan swasta dalam mengelola sumberdaya-sumberdaya yang ada dan 
membentuk suatu pola kemitraan antara pemerintah dan swasta untuk menciptakan lapangan kerja baru dan merangsan perkembangan kegiatan ekonomi (Badruddin, 2012). Pertumbuhan ekonomi yang tinggi dan berkelanjutan merupakan kondisi utama atau merupakan suatu keharusan bagi keberlangsungan pembangunan ekonomi dan peningkatan kesejahteraan (Tambunan, 2015).

Pertumbuhan ekonomi Kabupaten Lombok Tengah selama tahun 2012-2019 baik berdasarkan harga berlaku maupun berdasarkan harga konstan, sangat bergantung dari besarnya fluktuasi dari nilai PDRB yang terjadi setiap tahun. Berfluktuasinya nilai PDRB akan mencerminkan tinggi rendahnya pertumbuhan ekonomi yang terjadi yang menggambarkan kemampuan kinerja perekonomian kabupaten Lombok Tengah selama priode analisis. Pertumbuhan ekonomi kabupaten Lombok Tengah berdasarkan harga berlaku bergerak menaik pada tahun 2013 kemudian secara perlahan mengalami pergerakan yang menurun hingga tahun 2018. Meskipun pada tahun 2019 mengalami peningkatan tetapi masih lebih rendah dari tahun 2012-2017. Secara rata-rata pertumbuhan ekonomi kabupaten Lombok Tengah berdasarkan harga berlaku sebesar 11,00 persen. Bentuk kurva dari pertumbuhan ekonomi Kabupaten Lombok Tengah dapat dilihat dalam gambar berikut.

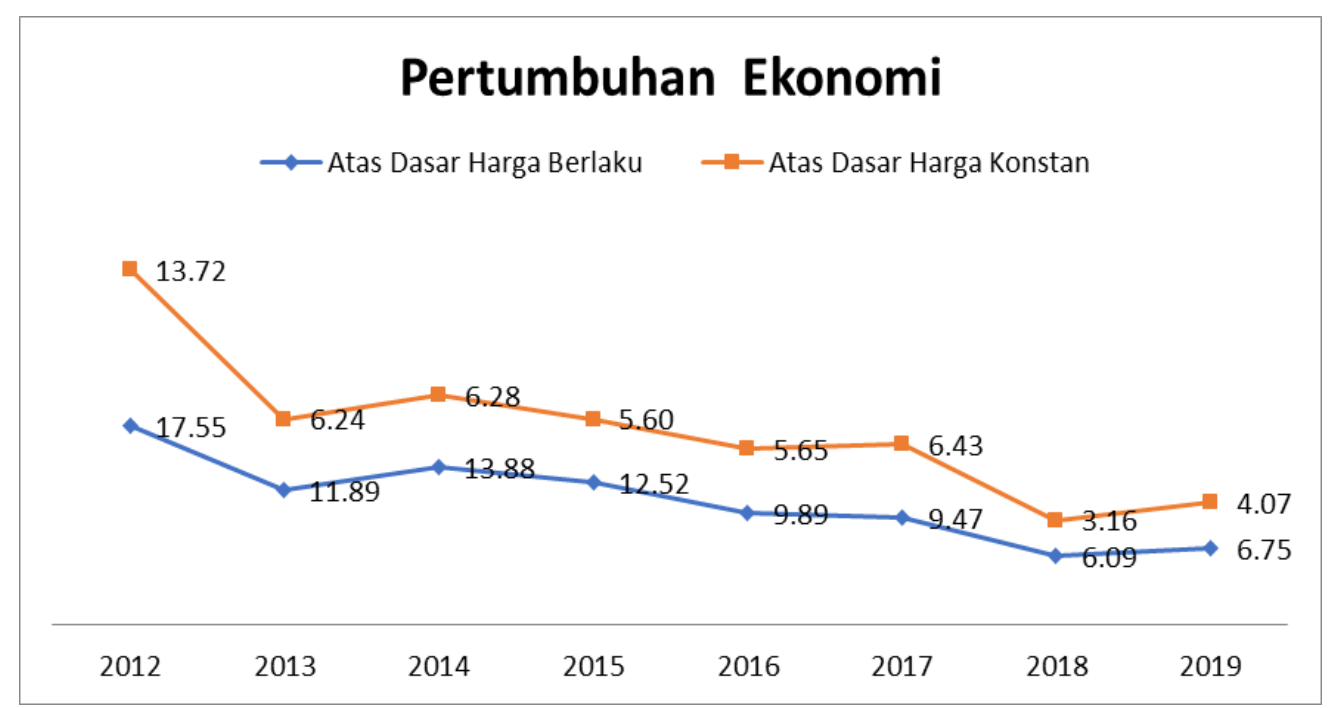

Gambar 1. Pertumbuhan Ekonomi Kabupaten Lombok Tengah Tahun 2012- 2019.

Pertumbuhan ekonomi kabupaten

Lombok Tengah berdasarkan harga konstan tahun 2010 justru tidak mengalami fluktuasi yang tajam bahkan cenderung berada dalam keadaan datar terkecuali pada tahun 2019 yang mengalami peningkatan setelah terjadi penurunan pada tahun 2018. 
Berdasarkan gambar ini, pertumbuhan ekonomi kabupaten Lombok Tengah berada dalam keadaan yang relatif sama, artinya tidak terjadi perubahan pertumbuhan yang signifikan. Secara ratarata pertumbuhan ekonomi kabupaten Lombok Tengah berdasarkan harga konstan adalah sebesar 6,39 persen. Ratarata pertumbuhan ekonomi tersebut telah mampu memberikan dorongan terhadap peningkatan aktivitas variabel-variabel ekonomi lainnya.

Pertumbuhan ekonomi yang tidak banyak mengalami perubahan atau pergerakannya sangat lambat merupakan cerminan dari kemampuan pemerintah kabupaten Lombok Tengah mengelola perekonomian daerahnya Pertumbuhan ekonomi yang dicapai pada tahun 2018 dan 2019 lebih rendah dari tahun-tahun sebelumnya merupakan dampak yang ditimbulkan oleh berbagai faktor baik eksternal maupun internal. Peristiwa gempa bumi yang melanda provinsi Nusa Tenggara Barat terutaman di pulau Lombok pada pertengahan tahun 2018 setidaknya telah memberikan kontribusi yang signifikan terhadap kinerja perekonomian Kabupaten Lombok Tengah. Kondisi inilah yang menyebabkan pertumbuhan ekonomi Kabupaten Lombok Tengah berdasarkan harga konstan mengalami penurunan yang sangat signifikan pula.

Recovery pembangunan ekonomi yang dilakukan oleh pemerintah Kabupaten Lombok Tengah pasca gempa bumi telah mampu dilakukan dengan meningkatnya pertumbuhan ekonomi pada tahun 2019 meskipun besarnya belum mampu menyamai capaian seperti yang terjadi pada tahun 2016 dan sebelumnya. Namun secara perlahan, ikhtiar meningkatkan pertumbuhan ekonomi seperti tahuntahun sebelumnya terus dilakukan. Berbagai kebijakan baik yang bersifat lokal maupun melanjutkan kebijakan-kebijakan yang bersifat nasional merupakan hal yang dilakukan oleh pemerintah Kabupaten Lombok Tengah. Pemerintah daerah kabupaten Lombok Tengah terus berupaya memaksimalkan potensi-potensi yang terdapat di daerahnya untuk menghasilkan nilai tambah terutama pada sektor-sektor ekonomi yang memiliki keunggulan dan keuntungan bagi pemerintah daerah Kabupaten Lombok Tengah. Sektor Pariwisata dan sektor industri Mikro, Kecil dan Menengah baik formal maupun non formal yang berbasis pertanian merupakan potensi yang sangat berpeluang untuk dikembangkan.

Pemerintah Daerah Kabupaten Lombok Tengah dalam upaya meningkatkan 
pertumbuhan ekonomi harus melihat beberapa faktor yang mempengaruhinya. Salah satu faktor yang mempengaruhi pertumbuhan ekonomi sebagaimana yang diungkpkan oleh Arsyad (2010) di atas adalah Akumulasi modal termasuk semua investasi baru yang berwujud tanah (lahan, peralatan fisik (mesinmesin) dan sumber daya manusia.. Pemerintah daerah Kabupaten Lombok Tengah telah dan akan berusaha secara maksimal untuk melakukan kegiatan investasi baik bersumber dari dana pemerintah maupun swasta. Pemerintah telah dan tengah berupaya untuk mengajak pihak-pihak swasta untuk melakukan investasi di kabupaten Lombok Tengah pada masa kini guna memperoleh hasil pada masa mendatang.

Pemerintah juga secara maksimal membangun fasillitas-fasilitas yang dapat menunjang aktivitas ekonomi masyarakat sehingga dapat memberikan nilai tambah pendapatan bagi pemerintah daerah. Pemerintah juga tetap memperhatikan pembangunan sarana fisik di bidang pertanian seperti irigasi yang diharapkan akan meningkatkan produktivitas sektor pertanian guna menghasilkan output yang tinggi. Peningkatan kualitas sumber daya manusi juga menjadi pusat perhatian pemerintah daerah. Pemenuhan kebutuhan dasar masyarakat di bidang pendidikan baik di sektor formal maupun non-formal terus dilakukan. Hal ini dimaksudkan agar sumber daya manusia memiliki ilmu pengetahuan, keterampilan dan keahlian yang semuanya bermuara pada peningkatan nilai tambah sektorsektor ekonomi yang bermuara pada peningkatan pertumbuhan ekonomi.

Pertumbuhan ekonomi kabupaten Lombok Tengah yang mengalami peningkatan dari tahun ke tahuh merupakan salah satu harapan dari proses pembangunan yang dilalukan oleh pemerintah daerah Kabupaten Lombok Tengah. Peningkatan pertumbuhan ekonomi ini diharapkan akan diikuti oleh terjadinya perubahan pada variabel variabel ekonomi lainnya seperti terbukanya kesempatan kerja baru yang secara otomatis akan diikuti oleh berubahnya angka pengangguran dan juga berdampak pada berubahnya penduduk yang masih tergolong miskin.

\section{Tingkat Pengangguran}

Ketenagakerjaan tidak dapat dipisahkan dari perkembangan penduduk, karena tenaga kerja bersumber dari penduduk. Salah satu faktor yang mempengaruhi pertumbuhan ekonomi adalah pertumbuhan penduduk. Pertumbuhan penduduk ini berkaitan dengan kenaikan 
jumlah angkatan kerja (labor force), secara tradiisional dianggap sebagai faktor yang positif dalam merangsang pertumbuhan ekonomi. Hal ini berarti (1) semakin banyak jumlah angkatan kerja berarti semakin banyak pasokan tenaga kerja, dan (2) semakin banyak jumlah penduduk akan meningkatkan potensi pasar domestik (Arsyad, 2010). Oleh karenanya, variabel ketenagakerjaan merupakan bagian yang tak terpisahkan dari pertumbuhan ekonomi.

Kondisi ketenagakerjaan yang dianalisis bekaitan dengan pertumbuhan ekonomi adalah banyaknya jumlah penduduk yang masih tergolong sebagai pengangguran. Jumlah atau besarnya penduduk umumnya dikaitkan dengan pertumbuhan income per kapita suatu negara, yang secara kasar mencerminkan kemampuan ekonomi negara tersebut (Mulyadi, 2012). Sebagai amanah dari sasaran fundamental pembangunan daerah, masalah pengangguran juga menjadi salah satu masalah prioritas yang harus ditangani oleh pemerintah Kabupaten Lombok Tengah. Hal ini dimaksudkan agar dapat dicapai tujuan untuk mewujudkan terciptanya penduduk yang berkualitas sebagai salah satu modal dasar pembangunan daerah kabupaten Lombok Tengah. Terciptanya penduduk yang berkualitas akan menjadi salah satu indikator bahwa proses pembangunan di kabupaten Lombok Tengah telah berjalan dengan baik dan mengalami kemajuan dari keadaan sebelumnya.

Perkembangan ketenagakerjaan di Kabupaten Lombok Tengah selama tahun 2012-2019 terjadi fluktuasi seiring dengan semakin bertambahnya penduduk yang masuk ke dalam usia kerja (tenaga kerja). Jumlah penduduk yang masih tergolong menganggur di Kabupaten Lombok Tengah pada tahun 2012 sebesar 26.011 orang mengalami penurunan menjadi sebanyak 11.802 orang pada tahun 2019. Dengan demikian dalam kurun waktu 8 tahun terjadi penurunan jumlah penduduk yang menganggur sebanyak 14.209 orang atau rata-rata sabanyak 1.776 orang setiap tahun. Kondisi ini mengindikasikan bahwa selama kurun waktu tersebut pemerintah daerah Kabupaten Lombok Tengah telah mampu memberikan kesempatan kerja pada penduduknya sehingga penduduk yang tergolong menganggur telah memiliki kesempatan kerja yang secara otomatis diikuti pula dengan terciptanya pendapatan bagi penduduk tersebut.

$\begin{array}{llr}\text { Pertumbuhan } & \text { penduduk } & \text { yang } \\ \text { menganggur } & \text { setiap } & \text { tahun } \\ \text { mengindikasikan } & \text { terjadinya } & \text { proses }\end{array}$


perubahan jumlah penduduk setiap tahun baik mengalami peningkatan maupun penurunan. Dilihat dari pertumbuhan jumlah penduduk yang menganggur, selama priode analisis secara rata-rata pertumbuhan pengangguran di kabupaten
Lombok Tengah mencapai $-8,25$ persen. Artinya terjadi penurunan jumlah penganggur sebanyak 8,25 persen sebagaimana terlihat dalam gambar berikut,

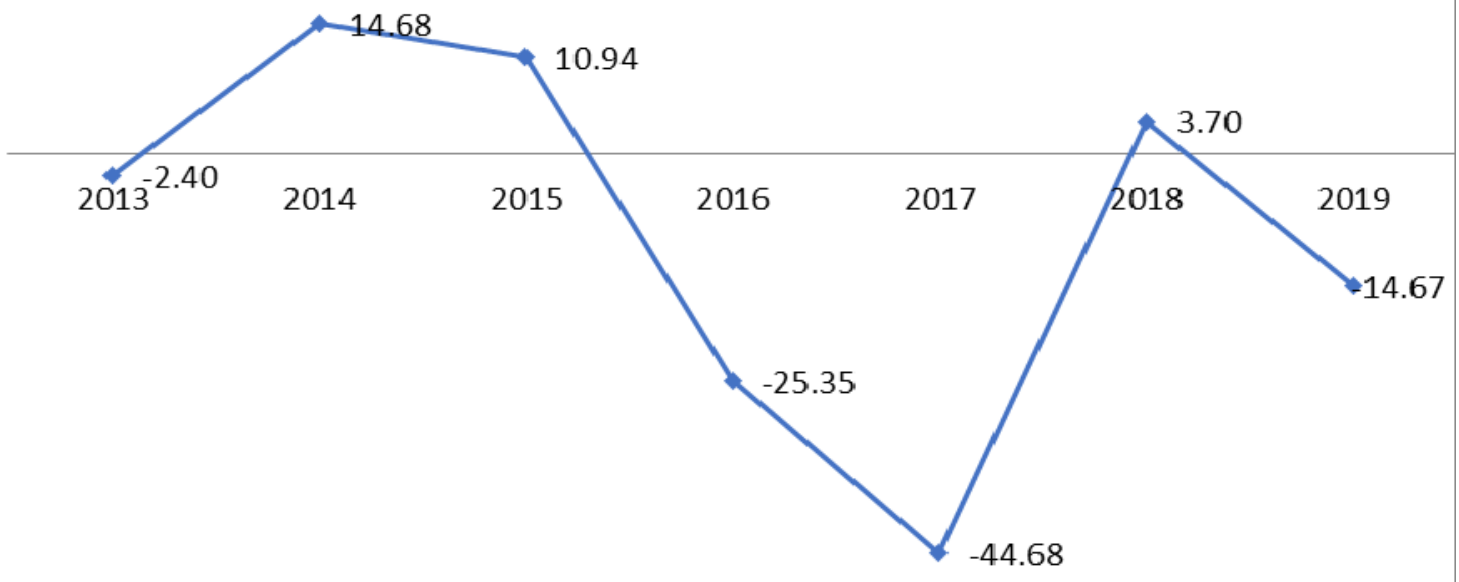

Gambar 2. Pertumbuhan Jumlah Penduduk Yang Menganggur Di Kabupaten Lombok Tengah Tahun 2013- 2019.

Jumlah pengangguran di Kabupaten Lombok Tengah sejak tahun 2015-2017 menunjukkan kecenderungan mengalami penurunan. Namun dengan terjadinya musibah gempa bumi yang melanda pulau Lombok khususnya pada tahun 2018 berdampak pada peningkatan jumlah pengangguran. Atas ikhtiar yang maksimal jumlah penduduk yang menganggur kembali menurun pada tahun 2019. Penurunan jumlah penduduk yang menganggur di Kabupaten Lombok Tengah sejalan dengan semakin berkembangnya aktivitas yang terjadi pada beberapa sektor terutama sektor pariwisata yang tengah mengalami perkembangan yang cukup menggembirakan. Dibukanya daerahdaerah tujuan wisata baru, dtunjang dengan pembangunan fasilitas-fasilitas merupakan kesempatan kerja baru yang disediakan untuk penduduk guna melakukan aktivitas usahanya.

Jumlah penduduk yang menganggur dapat diketahui lebih lanjut dengan melihat tingkat pengangguran terbuka. Tingkat pengangguran terbuka diukur sebagai persentase jumlah penganggur terhadap 
jumlah angkatan kerja (Kuncoro, 2013). Tinggi rendahnya TingkatPengangguran Terbuka (TPT)sangat bergantung pada ketersediaan tenaga kerja dalam menampung jumlah angkatan kerja baru yang memasuki pasar kerja. Diketahuinya Tingkat Pengangguran Terbuka (TPT) setiap tahun, menunjukkan tingkat keberhasilan dari program ketenagakerjaan dari tahun yang satu dengan tahun yang lainnya sekaligus sebagai bahan evaluasi pembangunan perekonomian kabupaten Lombok Tengah bila masih ditemukan jumlah penduduk yang tergolong sebagai penganggur.

Tingkat Pengangguran Terbuka (TPT) di Kabupaten Lombok Tengah cenderung mengalami fluktuasi dari tahun ke tahunnya. Terjadinya penambahan jumlah angkatan kerja yang memasuki pasar kerja, diimbangai pula dengan tersedianya kesempatan kerja pada masing-masing sektor ekonomi baik yang bersifat formal maupun non formal, mempengaruhi perkembangan jumlah penduduk yang tergolong menganggur. TPT yang tinggi mencerminkan angkatan kerja yang bertambah belum mampu diimbangi dengan tersedianya kesempatan kerja, demikian sebaliknya. Pola pergerakan Tingkat Pengangguran Terbuka (TPT) di Kabupaten Lombok Tengah dapat dilihat dalam gambar berikut.

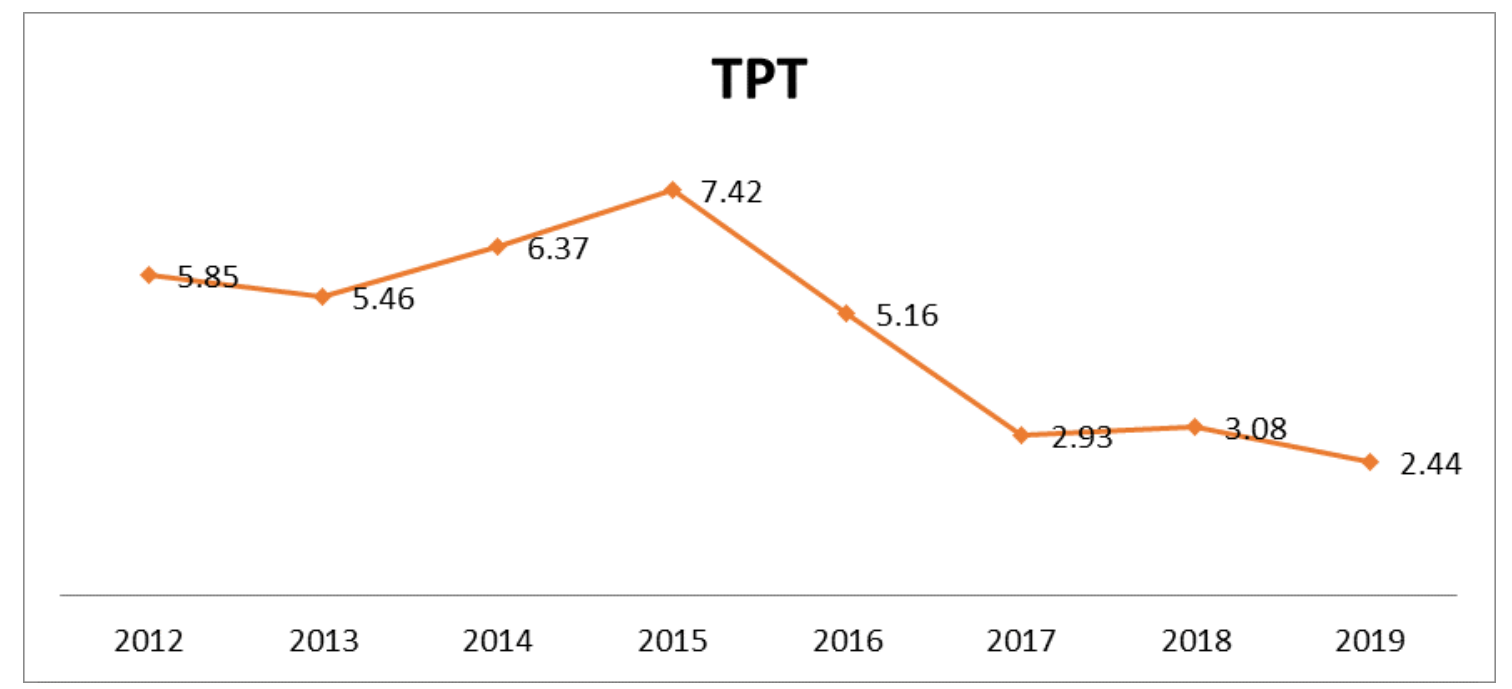

Gambar 3. Tingkat Pengangguran Terbuka (TPT) di Kabupaten Lombok Tengah Tahun $2012-2019(\%)$.

Peningkatan jumlah penduduk yang tergolong angkatan kerja membawa dampak semakin meningkatnya penduduk yang memasuki dan mencari lapangan kerja. Banyak sedikitnya angkatan kerja yang memperoleh kesempatan kerja sangat tergantung pada permintaan maupun penawaran tenaga kerja di pasar 
kerja, juga ketersediaan angkatan kerja untuk menciptakan lapangan kerja secara mandri agar terhindar dari julukan sebagai penganggur. Berdasarkan pada gambar di atas, terlihat bahwa pola pergerakan Tingkat Penganggutan Terbuka (TPT) terus mengalami penurunan secara kontinyu dari tahun 2015-2019 terkecuali pada tahun 2018 yang mengalami peningkata. Secara rata-rata Tingkat Pengangguran Terbuka di Kabupaten Lombok Tengah sejak tahun 2012 - 2019 adalah sebsar 4,83 persen. Artinya secara rata-rata masih terdapat penduduk yang tergolong menganggur yang masih membutuhkan penanganan dan perhatian dari pemerintah Kabupaten Lombok Tengah.

Pola pergerakan Tingkat Pengangguran Terbuka (TPT) yang berfluktuatif, menjadi perhatian pemerintah untuk dilakukan kajian yang mendalam mengenai berbagai faktor penyebab keberhasilan dan penghambat menurunnya jumlah penangguran. Kajian mengenai pengangguran harus dilakukan secara menyeluruh dan komprehensif baik yang bersifat internal kelompok umur, jenis kelamin, tingkat pendidikan maupun yang bersifat eksternal seperti kondisi lingkungan, stabilitas perekonomian maupun kebijakan pemerintah. Diketahuinya berbagai faktor yang berkenaan dengan pengangguran akan memudahkan pemerintah melakukan indentifikasi terhadap skala prioritas yang ingin dilakukan berkenaan dengan kebijakan di bidang ketenagakerjaan baik bersifat khusus maupun umum.

Berdasarkan uraian di atas, dapat diketahui bahwa pemerintah Kabupaten Lombok Tengah masih dihadapkan dengan permasalahan penduduk yang masih mengganggur yang belum dan sedang mencari lapangan pekerjaan. Hadirnya aktivitas pembangunan secara fisik maupun semakin bergairahnya aktivitas ekonomi terutama pada sektor Usaha Mikro Kecil Menengah (UMKM) belum mampu memberikan kesempatan kerja bagi penduduk yang masih menganggur. Satu sisi pemerihtah berupaya untuk mencuptakan lapangan kerja baru terutama sektor-sektor formal, namun tidak dapat dimanfaatkan oleh penduduk yang tergolong menganggur. Ketertbatasan dan rendahnya kualitas yang dimiliki oleh penduduk yang mengganggur meruoakan salah satu faktor penyebabnya. Rendahnya kualitas tersebut menyebabkan mereka tidak mampu bersaing dengan tenaga kerja luar yang datang bekerja di Kabupaten Lombok Tengah. 
Meskipun secara perlahan pengangguran terus mengalami penurunan dari tahun ke tahun, namun masih pemerintah kabupaten Lombok Tengah terus berupaya untuk memberikan peluang dan kesempatan kerja bagi penduduk yang menganggur. Disadari bahwa banyak dampak negatif yang ditimbulkan oleh pengangguran salah satunya terjadi ketidakstabilan kondisi sosial ekonomi bahkan politik di daerah tersebut. Menurut Arsyad (2010) besarnya potensi permasalahan sosial dan ekonomi yang dapat terjadi mengikuti rendahnya daya serap tenaga kerja di antarnya adalah rendahnya kemampuan daya beli (purchasing power) masyarakat. Rendahnya daya beli disebabkan penduduk yang menganggur tidak memiliki pendapatan untuk melakukan konsumsi guna memenuhi kebutuhan minimalnya.

Pengangguran membawa dampak terhadap stabilitas ekonomi dan sosial. Secara ekonomi pengangguran menyebabkan masyarakat tidak dapat memaksimumkan kesejahteraannya yang mungkin dicapainya. Pengangguran akan berdampak langsung terhadap tinggi rendahnya pendapatan nasional maupun pendapatan regional daerah. Pengangguran dapat menyebabkan hilangnya mata pencaharian dan pendapatan terutama pada negara-negara yang sedang berkembang. Penduduk yang tidak memiliki mata pencaharian, pendaparan dan keterampilan akan semakin menambah deretan dan jumlah penduduk yang tergolong miskin.

Pengangguran dan Kemiskinan merupakan variabel ekonomi yang membawa dampak ketidakstabillan ekonomi baik secara mikro maupun makro. Oleh karenanya, pembahasan pengangguran akan lebih lengkap bila dilanjutkan dengan membahasa kemiskinan. Dengan mengetahui kondisi pengangguran dan kemiskinan akan menjadi pertimbangan utama bagi pemerirntah Kabupaten Lombok Tengah dalam menata dan merencanakan proses pembangunan ekonomi yang memihak pada masyarakat yang masih mengganggur dan tergolong miskin.

\section{Kemiskinan}

Kemiskinan bukanlah fenimena yang baru dalam kehidupan sosial. la merupakan fenomena sosial yang selalu menjadi atribut negara-negara dunia ketiga. Fenomena ini juga merupakan kebalikan dari kondisi yang dialami oleh negaranegara maju yang memiliki atribut sebagai negara modern (Setiadi dan Usman Kolip, 2011). Bagi bangsa Indonesia, kemiskinan 
merupakan permasalahan yang masih dihadapi hingga saat ini, dan mendapat perhatian yang utama dalam proses pembangunan sosial dan ekonomi karena hal tersebut merupakan amanah dari UUD 1945. Berkenaan dengan hal tersebut banyak program dan kebijakan pemerintah pusat maupun daerah yang digelontorkan berkenaan dengan kemiskinan ini.

Kemiskinan yang terdapat pada suatu negara maupun daerah-daerah dalam wilayah negara tersebut selain melaksanakan kebijakan yang terpusat, juga dilaksanakan secara otonomi oleh daerah yang bersangkutan. Oleh karenanya, kebijakan penanganan kemiskinan dilakukan secara bersamaan antara kebijakan pemerintah pusat dengan kebijakan pemerintah daerah. Banyak sekali paket-paket kebijakana penanganan kemiskinan yang telah dilakukan oleh pemerintah pusat dan daerah, dan secara perlahan telah mampu menurunkan penduduk miskin meskipun belum sampai menuntaskan secara total permasalahan kemiskinan.

Kinerja pemerintah kabupaten Lombok Tengah dilihat dari pertumbuhan ekonomi telah memberikan hasil yang cukup menggembirakan meskipun belum mencapai harapan yang dituju. Demikian halnya yang berkenaan dengan permasalahan pengangguran telah mengalami penurunan dengan terciptanya lapangan kerja baru. Yang berkenaan dengan kemiskinanpun oleh pemerinah Kabupaten Lombok Tengah telah dilakukan berbagai kebijakan yang mengarah pada peningkatan kualitas hidup penduduk atau sumber daya manusia dengan menurunkan jumlah penduduk yang masih tergolong miskin. Karena disadari kemiskinan akan membawa dampak yang sangat signifikan terhadap proses pembangunan yang tengah dan akan dilaksanakan.

Perkembangan penduduk miskin di kabupaten Lombok Tengah baik secara mutlak maupun persentase mengalami fluktuatif dari tahun ke tahun. Pada tahun tertentu jumlah penduduk miskin mampu diturunkan dalam jumlah yang relatif banyak namun pada tahun lainnya mengalami penurunan yang relatif sedikit. Hal tersebut disebabkan oleh berbagai faktor baik yang bersifat internal maupun ekternal. Kondisi jumlah pendudduk miskin tersebut berikut. 
Tabel 4. Jumlah, dan Perubahan Penduduk Miskin Di Kabupaten Lombok Tengah Tahun 2012 -2019.

\begin{tabular}{lrlr}
\hline No & Tahun & \multicolumn{2}{l}{ Jumlah (orang) } \\
\cline { 3 - 4 } & & Penduduk Miskin & Perubahan \\
\hline $\mathbf{1}$ & 2012 & 148.200 & - \\
$\mathbf{2}$ & 2013 & 145.200 & $(3.000)$ \\
$\mathbf{3}$ & 2014 & 145.180 & $(20)$ \\
$\mathbf{4}$ & 2015 & 147.940 & 2.760 \\
$\mathbf{5}$ & 2016 & 145.370 & $(2.570)$ \\
$\mathbf{6}$ & 2017 & 142.142 & $(3.228)$ \\
$\mathbf{7}$ & 2018 & 130.000 & $(12.142)$ \\
$\mathbf{8}$ & 2019 & 128.820 & $(1.180)$ \\
\hline
\end{tabular}

Sumber : BPS NTB, Kabupaten Lombok Tengah Dalam Angka, 2013-2020, diolah.

Terlihat fluktuasi jumlah penduduk miskin

di Kabupaten Lombok Tengah cenderung mengalami penurunan kecuali tahun 2015 mengalami peningkatan yang cukup signifikan dibandingkan tahun-tahun sebelumnya. Peningkatan jumlah penduduk miskin ini tidak hanya terjadi di Kabupaten Lombok Tengah, namun seluruh wilayah kabupaten/kota di Provinsi Nusa Tenggara Barat juga mengalami peningkatan jumlah penduduk miskin. Hal ini dapat dimaknai, meskipun terdapat permasalahan yang bersifat lokal di kabupaten Lombok Tengah, peningkatan jumlah penduduk miskin pada tahun tersebut disebabkan juga oleh faktor-faktor ekternal yang terjadi secara merata di seluruh wilayah
Nusa Tenggara Barat maupun secara nasional.

Penurunan penduduk miskin yang paling banyak terjadi pada tahun 2019 mencapai 1.180 orang jauh lebih kecildi bandingkan dengan tahun 2018 yang mencapai 12.142 orang. Hal ini disebabkan karena pada pertengah tahun 2018 terjadi peristiwa gempa bumi yang melanda pulau Lombok tentunya membawa dampak terhadap aktvitias ekonomi yang berimbas terjadinya fluktuasi jumlah penduduk miskin di samping faktor-faktor lainnya. Kemampuan pemerintah kabupaten Lombok Tengah menurunkan jumlah penduduk miskin merupakan wujud dari ikhtiar yang telah dilaksanakan dengan mengeluarkan berbagai kebijakan baik yang dirasakan langsung oleh penduduk 
miskin maupun berbagai regulasi dan kebijakan. Secara rata-rata selama tahun 2012-2019 jumlah penduduk miskin mengalami penurunan sebanyak 2.423 orang setiap tahunnya.

Persentase penduduk miskin di Kabupaten Lombok Tengah juga mengalami perubahan seiring dengan terjadinya peningkatan jumlah penduduk setiap tahun. Meskipun jumlah penduduk terus mengalami penngkatan namun tidak diiimbangi dengan peningkatan persentase penduduk miskin. Persentase penduduk miskin di Kabupaten Lombok Tengah secara perlahan mengalami penurunan dari tahun ke tahun. Persentase penduduk miskin pada tahun 2012 mencapai 16,72 persen mengalami penurunan menjadi 13,63 persen pada tahun 2019 dengan penurunan rata-rata sebesar 15,48 persen per tahun. Meskipun secara persentase tergolong dalam jumlah relatif besar, pemernitah kabupaten Lombok Tengah dengan ikhtiar dan upaya yang maksimal telah mampu menurunkan penduduk dari jeratan kemiskinan baik secara jumlah maupun persentase. Lebih jelasnya terlihat dalam gambar berikut.

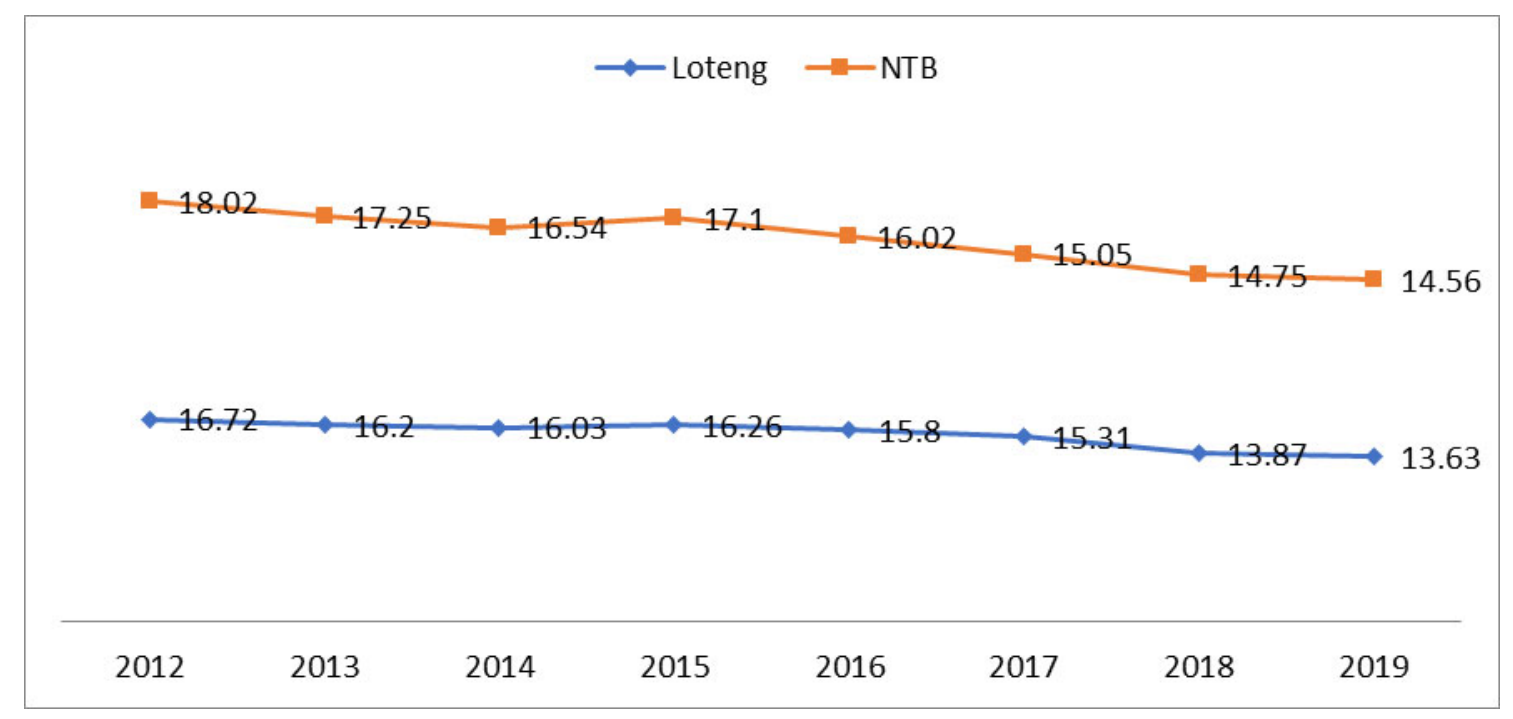

Gambar 4. Persentase Penduduk Miskin Di Kabupaten Lombok Tengah dan Provinsi Nusa Tenggara Barat Tahun 2012 - 2019(\%).

Pergerakan persentase penduduk miskin meskipun mengalami penurunan tetapi relatif datar artinya perubahan persentase kemiskinan secara rata-rata baru mencapai $-0,44$ persen setiap tahunnya. Namun demikian, persentase kemiskinan di Kabupaten Lombok Tengah dibanding dengan persentase kemiskinan di Nusa Tenggara Barat masih lebih rendah. Hal ini bermakna bahwa perubahan penduduk miskin secara persentase di Kabupaten Lombok Tengah relatif lebih tinggi 
dibanding dengan kabupaten/kota lainnya yang berada di Provinsi Nusa Tenggara Barat. Kondisi ini memberikan gambaran bahwa kabupaten Lombok Tengah termasuk salah satu kabupaten yang memiliki percepatan dalam penurunan penduduk miskin di Provinsi Nusa Tenggara Barat bersama dengan beberapa kabupaten/kota yang lainnya.

Menurunnya jumlah penduduk miskin dari tahun ke tahun mengindikasikan terjadinya peningkatan kualitas penduduk Kabupaten Lombok Tengah. Semakin bertambahnya penduduk yang tidak tergolong miskin menyebabkan terjadinya peningkatan daya beli terhadap berbagai kebutuhan dasarnya. Penduduk Kabupaten Lombok Tengah yang tidak tergolong miskin telah mampu memenuhi kebutuhan hidup minimalnya, baik yang berhubungan kebutuhan ekonomi maupun sosialnya. Secara perlahan proses pembangunan yang tengah dilaksanakan oleh Pemerintah Kabupaten Lombok Tengah akan mampu membawa masyarakatnya mencapai kesejahteraan sebagaimana yang menjadi tujuan pembangunan pemerintah Kabupaten Lombok Tengah.

Keberhasilan menurunkan persentase penduduk miskin merupakan suatu prestasi yang harus diberikan apresiasi meskipun belum mencapai hasil yang maksimal. Terjadinya penurunan penduduk miskin tidak terlepas dari kebijakan-kebijakan strategis pemerintah daerah Kabupaten Lombok Tengah seperti peningkatan dan perbaikan infrastruktur yang mempermudah akses penduduk untuk melakukan aktivitas ekonomi. Semakin berkembangnya aktivitas pembangunan baik fisik maupun non fisik pada seluruh sektor perekonomian merupakan salah satu faktor pendorong menurunnya jumlah penduduk miskin di Kabupaten Lombok Tengah. Tercpitanya kesempatan kerja bagi penduduk merupakan sumber pendapatan yang dapat dimanfaatkan untuk memenuhi berbagai kebutuhan baik yang bersifat primer, sekunder maupun tersier.

\section{KESIMPULAN DAN SARAN}

\section{Kesimpulan}

Berdasarkan analisis di atas, dapat ditarik beberapa kesimpulan sebagai berikut :

1. Produksi Domestik Regional Bruto (PDRB) Kabupaten Lombok Tengah baik berdasarkan harga berlaku maupun harga konstan tahun 20122019 terus mengalami peningkatan. Peningkatan ini memberikan indikasi bahwa sektor-sektor perekonomian yang berada di Kabupaten Lombok 
Tengah telah menghasilkan produkproduk yang mampu memberikan nilai tambah bagi penerimaan domestik pemerintah Kabupaten Lombok Tengah.

2. Produksi Domestik Regional Bruto (PDRB) Per Kapita Kabupaten Lombok Tengah baik berdasarkan harga berlaku maupun harga konstan tahun 2012-2019 juga mengalami peningkatan. Peningkatan pendapatan perkapita akan menyebabkan terjadinya peningkatan daya beli terhadap berbagai barang maupun jasa yang dibutuhkan oleh masyarakat.

3. Enam Sektor yang memberikan kontribusi terbesar dalam pembentukan PDRB Kabupaten Lombok Tengah masih berasal dari sektor pertanian dengan rata-rata sebesar 25,10 persen, diikuti oleh sektor transportasi dan pergudangan rata-rata sebesar 20,40 persen, sektor kontruksi rata-rata sebesar 11,56 persen, sektor Perdagangan besar, Reparasi Mobil dan Sepeda Motor rata-rata sebesar 10,90 persen, sektor Administrasi Pemerintahan, Pertahanan dan Jaminan Wajib Sosial rata-rata sebesar 5,92 persen dan sektor Industri Pengolahan rata-rata sebesar 5,10 persen.
4. Pertumbuhan ekonomi Kabupaten Lombok Tengah pada tahun 20122019 berdasarkan harga berlaku ratarata sebesar 11,00 persen sedangkan berdasarkan harga berlaku rata-rata sebesar 6,39 persen. Pertumbuhan ekonomi tersebut telah mampu menghantarkan kabupaten Lombok Tengah membangun daerahnya, terjadi perbaikan pembangunan kualitas sumberdaya manusia dilihat dari pengangguran maupun kemiskinan.

5. Jumlah penduduk yang menganggur di Kabupaten Lombok tengah sejak tahun 2012 -2019 telah terjadi penurunan menjadi 14.209 orang atau secara rata-rata mengalami penurunan sebesar 1.776 orang per tahun. Kondisi ini mengindikasikan bahwa selama kurun waktu tersebut pemerintah daerah Kabupaten Lombok Tengah telah mampu memberikan kesempatan kerja pada penduduknya sehingga penduduk yang tergolong menganggur telah memiliki kesempatan kerja yang secara otomatis diikuti pula dengan terciptanya pendapatan bagi penduduk tersebut.

6. Tingkat Pengangguran Terbuka (TPT) di Kabupaten Lombok Tengah tahun 
2012 - 2019 rata-rata sebesar 4,84 persen dengan TPT tertinggi terjadi pada tahun 2015 sebesar 7,42 persen dan terendah terjadi pada tahun 2019 sebesar 2,44 persen. Artinya secara rata-rata masih terdapat penduduk yang tergolong menganggur yang masih membutuhkan penanganan dan perhatian dari pemerintah Kabupaten Lombok Tengah.

7. Jumlah penduduk yang tergolong miskin di kabupaten Lombok Tengah juga mengalami penurunan dari berjumlah 148.200 orang pada tahun 2012 menjadi sebanyak 128.820 orang pada tahun 2019, terjadi penurunan sebesar 19.380 orang atau secara rata-rata sebanyak 2.423 orang pertahun. Jumlah penurunan terbanyak terjadi pada tahun 2013 sebanyak 29.300 orang dan yang terkecil terjadi pada tahun 2018 sebanyak 272.142 orang.

8. Meskipun terjadi penurunan jumlah penduduk, namun secara persentase masih relatif tinggi rata-rata sebesar 15,48 persen dengan persentase tertinggi terjadi pada tahun 2012 sebesar 16,72 persen dan yang terendah pada tahun 2019 sebesar 13,63 persen.

\section{Saran}

1. Pemerintah Kabupaten Lombok Tengah harus melakukan upaya maksimal untuk memanfaatkan potensi yang ada pada setiap sektor agar dapat memberi peningkatan nilai tambah terhadap PDRB setiap tahun guna meningkatkan pertumbuhan ekonomi yang terus meningkat.

2. Rata-rata Laju pertumbuhan ekonomi selama tahun 2012- 2019 berdasarkan harga konstan yang telah mencapai 6, hendaknya dipertahankan dan dtingkatkan lagi pada masa-masa mendatang agar mampu memberikan dampak positif terhadap aktivitas ekonomi sektor-sektor lainnya.

3. Pemerintah Kabupaten Lombok Tengah terus memalukan kebijakankebijakan yang mengarah pada terciptanya kesempatan kerja baru dengan memberikan peluang seluasluasnya kepada sektor Usaha Kecil Menengah baik formal maupun informal sehingga dapat memberikan kesempatan kerja baru bagi penduduk yang masih tergolong menganggur.

4. Berkenaan dengan upaya menurunkan penduduk miskin, selain membuka kesempatan kerja baru dengan memiliki pendapatan yang tetap, pemerintah terus melanjutkan berbagai program pengentasan 
kemiskinan yang telah direncanakan

baik kebijakan yang dilakukan

bersama-sama pemerintah pusat maupun kebijakan-kebijakan lokal yang mengarah pada -pro-poor

\section{DAFTAR PUSTAKA}

Arsyad, Lincolin. 2010. Ekonomi Pembangunan. Edisi 5. Yogyakarta, UPP STIM YKPN.

Badruddin, Rudy. 2012. Ekonomika Otonomi Daerah. Yogyakarta, UPP STIM YKPN.

Badan Pusat Statistik Kabupaten Lombok Tengah. Kabupaten Tengah Dalam Angka Tahun 2013 - 2020. Praya.

Badan Pusat Statistik Provinsi Nusa Tenggara Barat. Berita Resmi Statistik; Profil Kemiskinan Di Nusa Tenggara Barat Maret dan September 2012 -2019, Mataram.

Badan Pusat Statistik Provinsi Nusa Tenggara Barat. Berita Resmi Statistik ; Keadaan Ketenagakerjaan Di Nusa Tenggara Barat Peberuari dan Agustus 2012 -2019, Mataram.

Fahmi, Irham. 2018. Pengantar Perekonomian Indonesia, Teori Konsep dan Realita. Bandung, ALFABETA.

Huda, Nurul. Dkk. 2015. Ekonomi Pembangunan Islam. Jakarta. PT. PranadaMedia Group.

Jhingan, M.L. 2018. Ekonomi Pembangunan dan Perencanaan. Cetakan 18. Depok, Rajawali Pers.

Kuncoro, Mudrajat. 2004. Otonomi dan Pembangunan Daerah. Reformasi, Perencaan, Strategi dan Peluang. Jakarta. Erlangga.

2013. Mudah Memahami dan Menganalisis Indikator Ekonomi. Yogyakarta, UPP STIM YKPN.

Maipita, Indra. 2014. Mengukur Kemiskinan dan Distribusi Pendapatan. Yogyakarta. UPP STIM YKPN.

Mankiw, N. Gregory. Euston Quah dan Peter Wilson. 2013. Pengantar Ekonomi Makro. Jakarta, Salemba Empat.

Mulyadi, S. 2012. Ekonomi Sumber Daya Manusia Dalam Perspektif Pembangunan. Jakarta. PT. RadjaGrafindo Persada.

Nanga, Muana. 2001. Makro Ekonomi Teori Masalah dan Kebijakan. Edisi Perdana. Jakarta. PT RadjaGrafindo Persada. 
Pangiuk, Ambok. 2018. Pengaruh Pertumbuhan Ekonomi Terhadap Penurunan Kemiskinan Di Provinsi Jambi Tahun 2009 - 2013. Iltizam Journal Of Syariah Economics Research. Volume 2. No. 2, 2018.

Pemerintah Provinsi Nusa Tenggara Barat. 2019. Rencana Pembangunan Jangka Menengah (RPJMD) Provinsi Nusa Tenggara Barat Tahun 2019 - 2013., Mataram.

Pressman, Steven, 2000. Lima Puluh Pemikir Ekonomi Dunia. Jakarta; Murai Kencana PT RadjaGrafindo Persada.

Rahardja, Pratama dan Mandala Manurung. 2001. Teori Ekonomi Makro Suatu Pengantar. Jakarta, Lembaga Penerbit Fakultas Ekonomi dan Universitas Indonesi(LPFE-UI).

Setiadi. Elly M dan Usman Kolip. 2011. Pengantar Sosiologi. Pemahaman Fakta Dan Gejala Permasalahan Sosial, Teori Aplikasi dan Pemecahannya. Jakarta. Kencana Prenada Media Group.

Stamboel, Kemal A. 2012. Panggilan Keberpihakan Strategi Mengakhiri Kemiskinan di Indonesia. Jakarta. PT. Gramedia Pustaka Utama.

Subandi. 2019. Ekonomi Pembangunan. Bandun, Alfabeta.

Sumarsono, Sony. 2009. Teori dan Kebijakan Publik. Ekonomi Sumber Daya Manusia. Yogyakarta, Graha Ilmu.

Sun'an, Muammil dan Abdurrahman Senuk. 2015. Ekonomi Pembangunan Daerah. Jakarta. Mitra Wacana Media.

Suroto, 1993. Strategi Pembangunan dan Perencanaan Kesempatan Kerja, Yogyakarta, Gadjah Mada Univesity Press.

Suwandika, Putu Eka dan I Nyoman Mahendra Yasa. 2015. Pengaruh Pendapatan Asli Daerah Dan Investasi Terhadap Pertumbuhan Ekonomi dan Tingkat Pengangguran di Provinsi Bali. E-Jurnal Ekonomi Pembangunan Universitas Udayana Vol 4. No. 7 Juli 2015.

Tambunan, Tulus T.H. 2015. Perekonomian Indonesia Era Orde Lama Hingga Jokowi. Bogor. Ghalia Indonesia.

, 2019. Pembangunan Ekonomi Perdesaan Berbasis Pariwisata Dan Ekonomi Kreatif. Bandung, CV. Pustaka Setia. 